УДК $342.9+349.6+553.3 / 9$

DOI https://doi.org/10.32837/pyuv.v0i2(27).191

Ю. О. Легеза

доктор юридичних наук, доиент, професор кафедри цивільного, господарського та екологічного права Національного технічного університету «Дніпровська політехніка»

\title{
ОКРЕМІ АСПЕКТИ ЗАСТОСУВАННЯ ЗАХОДІВ АДМІНІСТРАТИВНОЇ ВІДПОВІДАЛЬНОСТІ ЗА ВЧИНЕННЯ ЕКОЛОГІЧНИХ ПРАВОПОРУШЕНЬ
}

Адміністративні процедури, поетапно регламентуючи порядок здійснення відносин між суб'єктами публічної адміністрації як репрезентантами публічних інтересів та приватними особами, являють собою вагомий операційний елемент механізму публічного управління. У контексті нових підходів до моделі управління у сфері використання природних ресурсів, відтворення їх потенціалу, охорони навколишнього природного середовища, забезпечення природоресурсної та екологічної безпеки особливого значення набуває питання про трансформаційні перетворення системи організації контрольно-інспекційних функцій в новій моделі управління природокористуванням як на загальнодержавному, так і на регіональному рівнях.

Реалізація контрольно-інспекційних функцій у контексті започаткованої адміністративної реформи має поступово наблизитись до запровадження принципу обов'язкового роз'єднання їх 3 функціями охорони довкілля та у своїй новій моделі набути рис системності, комплексності та однозначної повноцінності для різних сфер природокористування - загального, земельного, водного, надрокористування, поводження з відходами, забезпечення радіоекологічної безпеки тощо.

Побудована за вищезазначеними принципами система органів управління у сфері раціонального використання природних ресурсів, охорони довкілля та забезпечення ресурсної і екологічної безпеки буде відповідати загальновизнаній логіці суб'єкт-об'єктних відносин, тобто відсутності ситуації підпорядкування контрольних органів тій системі, стосовно якої вони здійснюють контроль, та дійсно реалізовувати принципи дотримання національних інтересів України щодо переходу до збалансованого природокористування та сталого розвитку завдяки впровадженню адекватних інституційних перетворень та відповідних заходів адміністративної реформи.

Певні аспекти відповідальності відображено у працях таких вчених, як С.С. Алексєєв, Б.С. Антимонов, О.С. Іоффе, М.С. Малеїн, Г.К. Матвєєв, В.О. Тархов. Серед вітчизняних правників правову регламентацію адміністративної відповідальності досліджували Н.О. Армаш, Т.О. Коломоєць, В.К. Колпаков, А.Т. Комзюк, О.І. Миколенко, С.Г. Стеценко та інші.
Метою статті є вирішення проблем оптимізації механізму застосування заходів адміністративної відповідальності за вчинення екологічних правопорушень.

Теоретичне опрацювання проблем юридичної відповідальності дозволяє охарактеризувати ії як складне й багатоаспектне явище. Теоретико-правові дослідження, спрямовані на визначення сутності юридичної відповідальності, дозволили виокремити певні їі риси. Як справедливо зазначає С.С. Алексєєв, сутністю юридичної відповідальності є застосування до винної особи заходів державного примусу за вчинене правопорушення [1, c. 48].

На зв'язку юридичної відповідальності з державним примусом за вчинене правопорушення наполягає і В.В. Лазарєв, підкреслюючи при цьому, що притягнення до відповідальності винної особи пов'язане із зазнанням винним позбавлень особистого (організаційного) або майнового характеру [2, с. 490].

Сучасний теоретико-правовий аналіз концепцій юридичної відповідальності, проведений у працях I.A. Сердюка, дозволив визначити їі як «здійснюваний у межах правовідносин добровільно або за рішенням судового чи іншого юрисдикційного органу та забезпечений державою юридичний обов'язок правопорушника зазнати позбавлення певних цінностей, що йому належали» [3, с. 50].

Різні аспекти адміністративної відповідальності завжди належали до найбільш обговорюваних у юридичних колах питань. Особливі відмінності у поглядах в науковому співтоваристві спостерігаються щодо проблеми відповідності санкцій за вчинене діяння ступеню суспільної небезпечності цього діяння. Не сприяє теоретичній усталеності цієї теми у вигляді розробки єдиного підходу до їі розуміння й відсутність законодавчого визначення поняття адміністративної відповідальності, тому вона залишається предметом постійних наукових досліджень.

Фундаментальний підхід до визначення поняття адміністративної відповідальності запропонований В.К. Колпаковим та О.В. Кузьменко. Згідно цим підходом вона полягає у примусовому застосуванні з дотриманням встановленої процедури правомочним суб'єктом передбачених законодав- 
ством за вчинення адміністративного проступку заходів впливу щодо правопорушника [4, с. 252].

Подібне бачення проблеми знаходимо в працях В.Б. Авер'янова, відповідно до думки якого адміністративна відповідальність - це різновид юридичної відповідальності, що являє собою сукупність адміністративних правовідносин, які виникають у зв'язку із застосуванням уповноваженими органами чи їх посадовими особами до осіб, які вчинили адміністративний проступок, передбачених нормами адміністративного права особливих санкцій - адміністративних стягнень [5, с. 430-431].

I.А. Беленчук зробив акцент на тому, що адміністративна відповідальність настає внаслідок невиконання вимог адміністративного законодавства і полягає у реакції держави на вчинення адміністративного правопорушення [6, с. 77].

Однак при цьому не визначено, що розуміється під поняттям «адміністративне законодавство», не враховано бланкетність більшості норм адміністративного законодавства, що встановлює відповідальність за вчинення адміністративних правопорушень.

Більшість вчених, визначаючи поняття адміністративної відповідальності, зосереджує увагу на застосуванні до винних у вчиненні адміністративних правопорушень (проступків) чи інших порушень адміністративного законодавства адміністративних стягнень (Г.П. Бондаренко [7, с. 84], С.Т. Гончарук [8, с. 19]).

На відміну від цивільно-правової відповідальності адміністративна відповідальність не виконує компенсаційної функції.

А.П. Гетьман та М.В. Шульга вважають, що суб'єктами правопорушень можуть бути як окремі громадяни і посадові особи, так і підприємства, установи і організації - юридичні особи. Правопорушниками в галузі використання природних ресурсів можуть бути і державні органи управління чи органи місцевого самоврядування, які, наприклад, незаконно розпоряджаються природними ресурсами, порушують встановлений порядок передачі природних ресурсів у власність або надання їх у користування. Суб'єкти правопорушень у сфері використання природних ресурсів - фізичні і юридичні особи - не обов'язково повинні бути власниками природних ресурсів чи природокористувачами або взагалі носіями інших спеціальних прав на використання природних ресурсів. Зазначені правопорушення можливі, наприклад, з боку проектних організацій, які розробляють проекти розташування і будівництва об'єктів, містобудівну документацію тощо [9].

Підтримують концепцію доцільності застосування заходів адміністративної відповідальності до юридичних осіб також П.С. Лютіков [10, с. 635-641] та М.Ю. Віхляєв [11, с. 13].
Вважаємо за потрібне зупинитися на цьому моменті для чіткішого окреслення проблемних зон, пов'язаних із застосуванням адміністративної відповідальності як методу публічного управління у сфері використання природних ресурсів у сучасних умовах нашої держави.

Однією з основних проблем, яка вимагає наукового розгляду та практичного коригування, ми вважаємо пошук єдиного підходу до розуміння доцільності та можливості притягнення до адміністративної відповідальності за вчинення порушень природоресурсного законодавства юридичних осіб. Сукупність економічних, господарських санкцій, що до них застосовуються, є за своєю сутністю заходами адміністративної відповідальності [12, с. 314].

Адміністративні санкції до юридичних осіб нині передбачені такими законами України: «Про ветеринарну медицину», «Про забезпечення санітарного та епідемічного благополуччя населення», «Про виключну (морську) економічну зону» тощо. Зокрема, згідно із Законом України «Про виключну (морську) економічну зону» юридичні особи несуть відповідальність за незаконну промислову діяльність (ст. 22), порушення правил безпечної експлуатації споруд (ст. 23), незаконну експлуатацію природних ресурсів (ст. 24), незаконне ведення морських наукових досліджень (ст. 25), забруднення морського середовища (ст. 26) [13].

Однак не у всіх сферах, де використовуються природні ресурси, діють спеціальні законодавчі акти, які мають встановлювати відповідальність саме юридичних осіб. Зокрема, в межах реалізації Закону України «Про регулювання містобудівної діяльності» [14] має бути передбачена відповідальність за порушення правил забудови населених пунктів, порушення природного ландшафтного різноманіття тощо. Вимагається визначення заходів адміністративної відповідальності, які можуть бути застосовані до юридичних осіб за забруднення ними земель, водних ресурсів та інших природних ресурсів, що сталися внаслідок порушення порядку розміщення, транспортування, утилізації техногенних відходів тощо.

Попри те, що законодавець не називає відповідальність юридичних осіб адміністративною, вона за всіма ознаками є саме такою, оскільки за відповідні правопорушення на юридичних осіб накладаються адміністративні санкції - штрафи, конфіскація засобів і знарядь, із застосуванням яких були вчинені правопорушення, конфіскація незаконно добутих природних ресурсів.

Крім того, до юридичних осіб, винних у порушенні режиму використання природних ресурсів, можуть бути застосовані адміністративно-господарські санкції.

Особливостями адміністративно-господарських санкцій за порушення режиму використан- 
ня природних ресурсів, що виявляють їх сутність, є такі риси:

1) вони встановлюються за порушення правил здійснення господарської діяльності, пов'язаної з використанням природних ресурсів, а не за порушення договірних зобов'язань;

2) вони застосовуються до суб'єктів господарювання;

3) на відміну від господарських санкцій, що застосовуються внаслідок порушень умов господарсько-правового договору, адміністративно-господарські санкції застосовуються уповноваженими органами державної влади або органами місцевого самоврядування, а не іншими органами чи стороною в зобов' язанні;

4) встановлюються адміністративно-господарські санкції винятково законами, а не підзаконними актами чи договором, якими визначаються види цих санкцій, порядок та підстави їх застосування [15, с. 152].

Відповідно до статті 239 Господарського кодексу України визначено такий перелік адміністративно-господарських санкцій: вилучення прибутку (доходу); адміністративно-господарський штраф; стягнення зборів (обов' язкових платежів); застосування антидемпінгових заходів; припинення експортно-імпортних операцій; застосування індивідуального режиму ліцензування на умовах та в порядку, визначених законом; зупинення дії ліцензії (патенту) на здійснення суб'єктом господарювання певних видів господарської діяльності; анулювання ліцензії (патенту) на здійснення суб'єктом господарювання окремих видів господарської діяльності; обмеження або зупинення діяльності суб'єкта господарювання; ліквідація суб’єкта господарювання та інші види державних обмежень [16].

При аналізі юридичних осіб як суб'єктів юридичної відповідальності в галузі публічного управління у сфері використання природних ресурсів доречно також навести теоретичні висновки I.А. Куян, згідно з якими за правопорушення у сфері використання природних ресурсів не лише накладаються стягнення, передбачені у чинному Кодексі України про адміністративні правопорушення, але й вживається низка заходів адміністративного примусу, змістом яких є обмеження чи позбавлення особи спеціального права - права використання природних ресурсів чи об'єктів, права ведення екологічно значущої діяльності, в тому числі обмеження дії чи анулювання дозволів та ліцензій. Підстави для застосування таких заходів передбачені здебільшого у підзаконних нормативних актах (положеннях та інструкціях). Аналіз таких нормативних документів дозволив дослідниці дійти висновку, що подібні адміністративні санкції застосовуються як заходи припинення правопорушень і як адміністративні стягнення.
Порівняння ознак адміністративних санкцій, які спрямовані на позбавлення осіб (фізичних i юридичних) спеціальних прав (зокрема, зупинення дії, анулювання дозволів, ліцензій, зупинення чи припинення діяльності), дало підстави для підтвердження відсутності суттєвої різниці у змісті таких санкцій [17, с. 8].

На думку вченої, застосування адміністративних стягнень, які суттєво обмежують чи позбавляють особу (фізичну чи юридичну) спеціальних прав (права полювання, зупинення дії, анулювання дозволів, ліцензій, зупинення, заборона певних видів діяльності), має бути забезпечене максимумом гарантій, які переважно може дати судовий розгляд справи [17, с. 10$]$.

На практиці також вже відбувається поєднання заходів адміністративної відповідальності 3 іншими заходами попередження та припинення адміністративних правопорушень. Наприклад, у справі № 826/6868/14 Харківським окружним адміністративним судом за позовом Державної екологічної інспекції України прийняте рішення про накладення штрафу на фізичну особу-підприємця за вчинення правопорушення, передбаченого ст. 78 КУпАП, у розмірі 136 грн., а також рішення про зупинення його діяльності з переробки соняшникової олії через порушення вимог охорони навколишнього природного середовища [18].

Таким чином, адміністративні санкції за порушення режиму використання природних ресурсів у такому ракурсі можна визначити як сукупність заходів, спрямованих на припинення правопорушення, що застосовуються відповідними державними органами та їх посадовими особами до правопорушників у сфері використання природних ресурсів. При цьому до причин низької ефективності механізму притягнення до адміністративної відповідальності ми пропонуємо віднести морально застарілі розміри санкцій, встановлені чинним адміністративно-деліктним законодавством.

Погоджуючись з науковим підходом, що збільшення розміру адміністративних санкцій за вчинене адміністративне правопорушення не вирішить проблеми низької ефективності функціонування зазначеного механізму, водночас зазначимо, що у більшості статей розмір адміністративних штрафів, сплата яких, як правило, передбачається за порушення вимог природоресурсного законодавства, не переглядалась вже понад 10-15 років.

Наприклад, за вчинення правопорушення, передбаченого ст. 91-2 КУпАП, яке полягає у перевищенні затверджених лімітів та нормативів використання природних ресурсів, передбачається накладення штрафу на громадян від трьох до вісімнадцяти неоподатковуваних мінімумів доходів громадян, а на посадових осіб - від дев'яти до тридцяти неоподатковуваних мінімумів доходів громадян [19]. Розмір адміністративного штрафу 
за положеннями цієї статті не переглядався останніх 15-17 років. Це ж стосується й інших складів адміністративних правопорушень у сфері використання природних ресурсів (ст. ст. 78, 79, 82-6, 83-1, 86-1, 91 та ін.) [19].

Отже, розуміння комплексності підходів до застосування заходів адміністративної відповідальності у сфері використання природних ресурсів має керуватися забезпеченням реалізації концепції сталого розвитку, яка має бути покладена в основу методів, принципів та засобів публічного управління природоресурсним комплексом країни для спрямування їх на забезпечення формування перспективного природоресурсного потенціалу країни.

Таким чином, адміністративна відповідальність у сфері використання природних ресурсів розглядається нами як засіб публічного управління, який полягає у застосуванні до особи, винної у порушенні вимог природоресурсного законодавства (тобто фізичних та посадових осіб), адміністративних санкцій і реалізується в межах спеціально визначеної процедури відповідними органами державної влади.

При цьому застосування цього управлінського засобу для раціоналізації використання природних ресурсів в Україні має низку проблемних аспектів.

Стосуються вони визнання суб'єктами адміністративної відповідальності не лише фізичних, а й юридичних осіб, необхідності поєднання застосування заходів адміністративної відповідальності та відповідних адміністративно-господарських санкцій (вилучення прибутку (доходу), накладення адміністративно-господарського штрафу, обмеження або зупинення діяльності суб'єкта господарювання) до юридичних осіб - суб'єктів господарювання, внаслідок діяльності яких створюються умови для порушення визначеного режиму природокористування. Також ці проблемні аспекти стосуються необхідності загального перегляду встановлених законодавством санкцій за правопорушення у досліджуваній сфері та їх корекції в частині розмірів штрафу відповідно до вимог сьогодення.

Реалізація адміністративної відповідальності за правопорушення у сфері використання природних ресурсів відбувається шляхом здійснення провадження у справах про них. Вивченню такого провадження буде присвячений окремий підрозділ нашого дослідження.

\section{Jimepamypa}

1. Алексеев С.С. Право: азбука - теория - философия: опыт комплексного исследования. Москва : Статут, $1999.712 \mathrm{c.}$
2. Проблемы общей теории права и государства : учебник / под общ. ред. академика РАН, д.ю.н., проф. В.С. Нерсесянца. Москва : Норма, 2006. 832 с.

3. Сердюк I.A. Методологічний аналіз сучасних інтерпретацій поняття «юридична відповідальність». Право і суспільство. 2010. № 5. С. 45-50.

4. Колпаков В.К., Кузьменко О.В. Адміністративне право України : підручник. Київ : Юрінком Інтер, $2003.544 \mathrm{c}$.

5. Адміністративне право України. Академічний курс : підручник для студ. юрид. спец. вищих навч. закл. : у 2 т. / В.Б. Авер'янов, О.Ф. Андрійко, Ю.П. Битяк та ін. ; за ред. В.Б. Авер'янова. Київ : Юридична думка, 2004. Т. 1 : Загальна частина. 584 с.

6. Беленчук I.А Адміністративне право України : навчальний посібник. Київ : А.С.К., 2004. 176 с.

7. Старилов Ю.Н. Курс общего административного права : в 3 т. Москва : Норма, 2002. Т. 1 : История. Наука. Предмет. Нормы. Субъекты. 728 с.

8. Гончарук С.Т. Основи адміністративного права України : навчальний посібник. Київ : Аванпост-Прим, 2004. $200 \mathrm{c}$.

9. Екологічне право України : підручник / за ред. А.П. Гетьмана та М.В. Шульги. Харків : Право, 2009. 328 c.

10. Лютіков П.С. Адміністративна відповідальність юридичних осіб : теоретико-правовий аналіз. Форул права. 2013. № 1. С. 635-641.

11. Віхляєв М.Ю. Адміністративна відповідальність громадських об'єднань в Україні: проблеми нормативно-правового регулювання в контексті вступу в дію нового Закону України «Про громадські об'єднання». Віче. 2013. № 10. С. 11-13.

12. Костицький В. Десять тез про юридичну відповідальність за екологічні правопорушення. Про українське право: Часопис кафедри теорії та історії держави і права / КНУ ім. Тараса Шевченка. 2010. Число 5. Правова відповідальність. С. 312-322.

13. Про адміністративні послуги : Закон України від 06.09.2012 р. Відомості Верховної Ради. 2013. № 32. Ст. 409 .

14. Про регулювання містобудівної діяльності : Закон України від 17.02.2011 р. Відомості Верховної Ради України. 2011. № 34. Ст. 343.

15. Віхрова I.O. Адміністративно-господарські санкції як заходи господарсько-правової відповідальності. Часопис Київського університету права. 2015. № 2. C. 151-155.

16. Господарський кодекс України : Закон України № 436-IV від 16.01.2003 р. Відолості Верховної Ради України. 2003. № 18. Ст. 144.

17. Куян I.A. Адміністративна відповідальність за екологічні правопорушення : автореф. дис. ... канд. юрид. наук : 12.00.07. Київ, 2001. 20 с.

18. Постанова Харківського окружного адміністративного суду від 25.07.2016 р. № 820/3470/16. ЄӘиний державний реєстр судових рішень : офіційний веб-сайт. URL: http://reyestr.court.gov.ua/Review/ 59192135.

19. Кодекс України про надра від 27.07.1994 р. Відомості Верховноӥ Ради Украӥни. 1994. № 36. Ст. 340. 


\section{Анотація}

Легеза Ю. О. Окремі аспекти застосування заходів адміністративної відповідальності за вчинення екологічних правопорушень. - Стаття.

$\mathrm{V}$ науковій статті здійснено аналіз застосування заходів адміністративної відповідальності за вчинення екологічних правопорушень. Доцільність розуміння комплексності підходів до застосування заходів адміністративної відповідальності у сфері використання природних ресурсів має грунтуватися на позиції забезпечення реалізації концепції сталого розвитку, яка має бути покладена в основу методів, принципів та засобів публічного управління природоресурсним комплексом країни для спрямування їх на забезпечення формування перспективного природоресурсного потенціалу країни. Автором зроблено висновок, що адміністративна відповідальність у сфері використання природних ресурсів розглядається як засіб публічного управління, який полягає у застосуванні до особи, винної у порушенні вимог природоресурсного законодавства (тобто фізичних та посадових осіб), адміністративних санкцій і реалізується в межах спеціально визначеної процедури відповідними органами державної влади. Підкреслено, що застосування цього управлінського засобу для раціоналізації використання природних ресурсів в Україні має низку проблемних аспектів. Наголошено на доцільності визнання суб'єктами адміністративної відповідальності не лише фізичних, а й юридичних осіб, необхідності поєднання застосування заходів адміністративної відповідальності та відповідних адміністративно-господарських санкцій (вилучення прибутку (доходу), накладення адміністративно-господарського штрафу, обмеження або зупинення діяльності суб'єкта господарювання) до юридичних осіб - суб'єктів господарювання, внаслідок діяльності яких створюються умови для порушення визначеного режиму природокористування. Також наголошується на необхідності загального перегляду встановлених законодавством санкцій за правопорушення у досліджуваній сфері та їх корекції в частині розмірів штрафу відповідно до вимог сьогодення. Обгрунтовано пропозиції реалізації адміністративної відповідальності за правопорушення у сфері використання природних ресурсів. Реалізація адміністративної відповідальності за правопорушення у сфері використання природних ресурсів відбувається шляхом здійснення провадження у справах про них. Вивченню такого провадження буде присвячений окремий підрозділ нашого дослідження.
Ключові слова: адміністративна відповідальність, екологічні правопорушення, санкції, суб'єкт, підстава.

\section{Summary}

Leheza Yu. O. Certain aspects of application of administrative liability actions. - Article.

The scientific article analyzes the application of measures of administrative responsibility for committing environmental offenses. The author establishes the expediency of understanding the complexity of approaches to the application of measures of administrative responsibility in the use of natural resources should proceed from the position of ensuring the implementation of the concept of sustainable development, which should underpin the methods, principles and means of public management of the country's natural resource complex to direct them to ensure the formation of promising natural resource potential of the country. The author concludes that administrative responsibility in the field of natural resources is considered by us as a means of public management, which is to apply to a person guilty of violating the requirements of environmental legislation (i.e. individuals and officials), administrative sanctions and implemented within a specially defined procedure by relevant public authorities. It is emphasized that the use of this management tool to rationalize the use of natural resources in Ukraine has a number of problematic aspects. Emphasis is placed on the expediency of recognizing administrative responsibility not only for individuals but also for legal entities; the need to combine the application of measures of administrative responsibility and appropriate administrative and economic sanctions (withdrawal of profit (income); imposition of an administrative and economic penalty; restriction or termination of the activity of the economic entity) to legal entities - economic entities that result in the conditions for violation defined mode of nature management; the need for a general review of the sanctions imposed by law for the offenses in the research area and their correction in terms of the amount of the fine in accordance with the requirements of today. Proposals for the implementation of administrative liability for offenses in the field of the use of natural resources are substantiated by carrying out proceedings in cases concerning them, which will be devoted to a separate unit of this research.

Key words: administrative responsibility, environmental offenses, sanctions, subject, reason. 